\title{
Dual effects of human adipose tissue-derived mesenchymal stem cells in human lung adenocarcinoma A549 xenografts and colorectal adenocarcinoma HT-29 xenografts in mice
}

\author{
JUNG JOO RHYU ${ }^{1,2^{*}}, \mathrm{JUN}^{-W O N} \mathrm{YUN}^{2 *}$, EUNA KWON $^{2}, \mathrm{JEONG}^{2} \mathrm{KWAN} \mathrm{CHE}{ }^{3}$ and BYEONG-CHEOL KANG ${ }^{1-4}$ \\ ${ }^{1}$ Graduate School of Translational Medicine, Seoul National University College of Medicine; \\ ${ }^{2}$ Department of Experimental Animal Research, Biomedical Research Institute, Seoul National University Hospital; \\ ${ }^{3}$ Biomedical Center for Animal Resource and Development, N-BIO, Seoul National University, Seoul; \\ ${ }^{4}$ Designed Animal and Transplantation Research Institute, Institute of GreenBio Science Technology, \\ Seoul National University, Pyeongchang-gun, Gangwon-do, Republic of Korea
}

Received March 4, 2015; Accepted May 18, 2015

DOI: 10.3892/or.2015.4185

\begin{abstract}
Human adipose tissue-derived mesenchymal stem cells (hATMSCs) have great potential as a therapy for various diseases. However, emerging evidence shows that there are conflicting results concerning effects of hATMSCs on tumor progression. Our objective was to determine whether and how hATMSCs modulate tumor growth. After cancer cell lines were subcutaneously inoculated into BALB/c-nude and hairless severe combined immunodeficient mice, hATMSCs were intratumorally injected into the mice. The growth of the A549 tumors was inhibited by hATMSCs, yet that of the HT-29 tumors was significantly promoted by hATMSCs in the in vivo xenograft models. In vitro study using a co-culture system of cancer cells and hATMSCs was consistent with the in vivo experiments. To reveal the molecular events induced by hATMSCs in the xenograft models, global gene expression profiles of the A549 and HT-29 tumors in the absence or presence of hATMSCs were determined. Significant numbers of genes involved in biological processes were altered in the hATMSC-treated A549 tumors, whereas no biological process
\end{abstract}

Correspondence to: Professor Byeong-Cheol Kang, Graduate School of Translational Medicine, Seoul National University College of Medicine, 101 Daehak-ro, Jongno-gu, Seoul 110-744, Republic of Korea

E-mail: bckang@snu.ac.kr

${ }^{*}$ Contributed equally

Abbreviations: hATMSCs, human adipose tissue-derived mesenchymal stem cells; NF- $\kappa \mathrm{B}$, nuclear factor $\kappa \mathrm{B}$; MSCs, mesenchymal stem cells; BM-MSCs, bone marrow-derived mesenchymal stem cells; SCID, severe combined immunodeficiency

Key words: human adipose tissue-derived mesenchymal stem cells, tumor, A549 lung adenocarcinoma cells, HT-29 colorectal adenocarcinoma cells, $\mathrm{NF}-\kappa \mathrm{B}$, microarray was regulated by treatment with hATMSCs in the HT-29 tumors, reflecting the different effects of hATMSCs in the different types of cancer. Notably, histone cluster $1, H 2 a j$ and neuropeptide $Y$ receptor $Y 4$ were found to be expressed in direct or inverse proportion to tumor size in both xenograft models. In addition, nuclear factor $\kappa \mathrm{B}(\mathrm{NF}-\kappa \mathrm{B})$ p 65 was differentially phosphorylated by the hATMSCs dependent on the source of the cancer cells. In conclusion, the identified gene profiling and $\mathrm{NF}-\kappa \mathrm{B}$ signaling provide molecular evidence to explain the conflicting findings in tumor-MSC studies, although further study is needed to confirm these findings using various types of cancer.

\section{Introduction}

Mesenchymal stem cells (MSCs) are defined as cells possessing the ability of self-renewal, proliferation and differentiation into multiple lineages, including chondrocytes, osteoblasts and adipocytes (1). MSCs are known to have homing properties and can repair injured tissues; thus, MSCs demonstrate potential as therapy for organ defects, regeneration or certain other conditions, including bone defects $(2,3)$, hair loss (4), liver fibrosis (5), pancreatic islet transplantation, immunomodulation (6) and neuronal regeneration (7). MSCs can be found in various tissues, including bone marrow, umbilical cord blood, placenta and fat (8). Among these sites, adipose tissue is accessible and abundant for the isolation of adult stem cells. Therefore, human adipose tissue-derived MSCs (hATMSCs) obtained by relatively less invasive procedures are an attractive source for cell therapy.

Our previous study indicated that systemic transplantation of hATMSCs did not induce tumor development (9). MacIsaac et al (10) also showed that no malignancies were detected in normal mice treated with hATMSCs. However, in tumor models, MSCs have been reported to play a role in the process of carcinogenesis, tumor growth and metastasis, although numerous studies have reported contradicting results; some investigators found that MSCs promote tumor growth and others report that MSCs inhibit tumor growth (11). 
Maestroni et al (12) reported that mouse bone marrow-derived mesenchymal stem cells (BM-MSCs) inhibited the proliferation and growth of Lewis lung carcinoma and B16 melanoma. It was also reported that hBM-MSCs showed a tumor-suppressive effect in an experimental model of Kaposi's sarcoma (13). BM-MSCs also exhibited an inhibitory effect on A549 tumor cells both in vivo and in vitro experiments (14). In contrast, a promoting effect of MSCs on tumor growth was observed in other studies. Zhu et al (15) subcutaneously injected hBM-MSCs along with colon cancer cells, and promotion of angiogenesis and tumor growth were noted. $\mathrm{Xu}$ et al (16) showed that hBM-MSCs promoted the growth and metastasis of osteosarcoma. The tumor-promoting effect of BM-MSCs was also demonstrated by Tsai et al (17) in HT-29 cancer cells.

Some mechanisms of MSC-related tumor supporting effects have been reported, which include vascular (18) and tumor stromal support (19), immunosuppressive effects (20) and metastatic support (21). On the other hand, the tumor inhibitory mechanisms of MSCs could be due to cell cycle arrest (22), angiogenesis inhibition (23) and regulation of certain soluble factors, such as Wnt inhibitor, Dickkopf-related protein-1 (DKK-1), that may block tumor-related cell signaling pathways (24). Despite these explanations regarding the action of MSCs, the tumor modulation mechanisms of MSCs are extremely complicated and difficult to demonstrate. Thus, in order for the clinical use of MSCs as a novel cell therapy for various conditions, it is critical to understand the interactions between tumors and MSCs. In the present study, we investigated the tumor-modulatory effects of hATMSCs in several types of human cancer cells to clarify the roles of hATMSCs on human cancers and to determine the underlying mechanisms.

\section{Materials and methods}

Tumor cell lines. Human malignant melanoma cell line A-375, human lung adenocarcinoma cell line A549 and human colorectal adenocarcinoma cell line HT-29 were purchased from ATCC (Manassas, VA, USA). Human epidermoid carcinoma cell line A-431, human gastric carcinoma cell line NCI-N87 and human pancreatic adenocarcinoma cell line Capan-1 were obtained from the Korean Cell Line Bank (Seoul, Korea). The cell lines were cultured in RPMI-1640 supplemented with $10 \%$ fetal bovine serum (FBS) and $0.03 \%$ antibiotic-antimycotic (all from Gibco, Grand Island, NY, USA) at $37^{\circ} \mathrm{C}$ in a $5 \% \mathrm{CO}_{2}$ humidified chamber.

Isolation and characterization of hATMSCs. hATMSCs were prepared from surplus banked stem cells under good manufacturing practice conditions (RNL Bio, Seoul, Korea) and used as anonymized materials. In brief, human abdominal subcutaneous fat tissue was obtained by simple liposuction following informed consent from donors, digested with collagenase I $(1 \mathrm{mg} / \mathrm{ml})$, and filtered through a $100-\mu \mathrm{m}$ nylon sieve to remove cellular debris and centrifuged at $470 \mathrm{~g}$ for 5 min. The pellet was resuspended in RCME cell attachment medium (RNL Bio) containing 10\% FBS and cultured at $37^{\circ} \mathrm{C}$. After $24 \mathrm{~h}$, the cell medium was changed to RKCM cell growth medium (RNL Bio) containing 5\% FBS. When the cells reached $80-90 \%$ confluency, they were subcultured and expanded in RKCM medium until passage 3 . The immu- nophenotypes of the hATMSCs were analyzed using flow cytometric analysis. Trypsinized hATMSCs were suspended [1x10 ${ }^{6} \mathrm{hATMSCs} / 25 \mu \mathrm{l}$ of phosphate-buffered saline (PBS)] and stained with FITC-conjugated CD31, CD34 and CD45 antibodies and PE-conjugated CD73 and CD90 antibodies (BD Pharmingen, San Diego, CA, USA).

In vivo tumor xenograft models. Severe combined immunodeficient (SCID) and nude mice can be used as human tumor xenograft models (25). Six-week old female BALB/c-nude mice (Orient Bio Inc., Seongnam, Korea) and hairless SCID mice (Charles River, Wilmington, MA, USA) were housed in an environmentally controlled room $\left(22 \pm 2^{\circ} \mathrm{C}, 40-60 \%\right.$ humidity and a 12-h light cycle). The present study was approved by the Institutional Review Board (IRB) and the Institutional Animal Care and Use Committee (IACUC) of the Biomedical Research Institute at Seoul National University Hospital. Cancer cells $\left(5 \times 10^{6}\right)$ were subcutaneously inoculated into the back of mice. The injection was made through the subcutaneous layer of the cervicodorsal part of the animals. When the tumor volume reached close to $100 \mathrm{~mm}^{3}$, the mice were intratumorally injected with $1 \times 10^{5} \mathrm{hATMSCs}$ suspended in PBS or PBS once a week for 8 weeks ( $n=3-6 /$ group). The tumor size was measured twice a week using a caliper (Mitutoyo, Tokyo, Japan), and the tumor volumes were calculated as $\pi / 6 \times$ (volume $\mathrm{x}$ width $\mathrm{x}$ height) according to a previously described method (26). After sacrifice at 8 weeks, the tumor masses were removed, weighed and fixed in $10 \%$ neutral buffered formaldehyde solution for histological analysis or preserved at $-70^{\circ} \mathrm{C}$.

In vitro co-culture and trypan blue exclusion assay. A549 and HT-29 cancer cells $\left(1 \times 10^{5}\right)$ were co-cultured with hATMSCs in RPMI-1640 medium with 10\% FBS in 6-well plates for $72 \mathrm{~h}$. Indirect co-culture was conducted using Transwell inserts (0.4- $\mu \mathrm{m}$ pore size, polycarbonate membrane; SPL, Pocheon, Korea) in 6-well plates to prevent cell-to-cell contact. All of the experiments were conducted in triplicate. Total cell number was assessed by a trypan blue exclusion assay using a hemocytometer under a microscope.

Western blot analysis. The proteins were extracted using RIPA lysis buffer (Millipore, Bedford, MA, USA) containing $0.1 \%$ phosphatase inhibitor cocktail (Sigma-Aldrich, St. Louis, MO, USA) and protease inhibitor (Roche, Indianapolis, IN, USA). The protein concentrations were determined using a BCA protein assay kit (Pierce Biotechnology, Rockford, IL, USA). Protein samples were loaded for immunoblotting using antibodies against phosphorylated nuclear factor $\kappa \mathrm{B}(\mathrm{NF}-\kappa \mathrm{B})$ p65, $\beta$-actin (Cell Signaling Technology, Beverly, MA, USA), p-JAK3, p-STAT3 and $\beta$-catenin (Santa Cruz Biotechnology, Santa Cruz, CA, USA). Densitometry of the target bands was analyzed using ImageJ [National Center for Biotechnology Information (NCBI)].

RNA isolation and microarray analysis. Total RNA from the tumors was isolated using Ambion mirVana miRNA Isolation kit (Ambion, Austin, TX, USA). RNA quality was assessed using an Agilent 2100 Bioanalyzer using the RNA 6000 Nano Chip (Agilent Technologies, Amstelveen, The Netherlands), and 
A
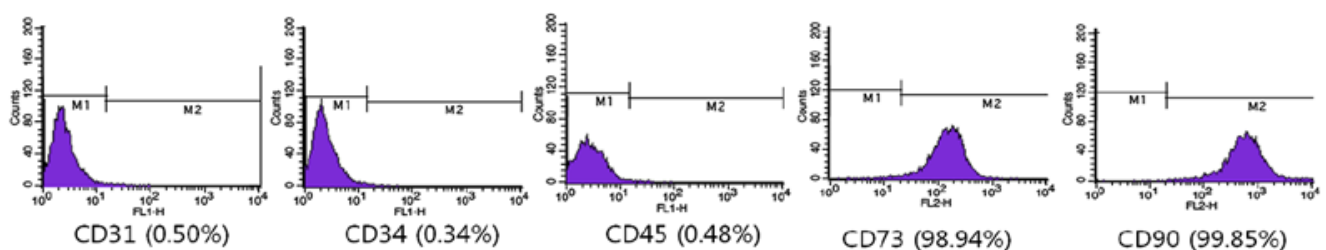

B
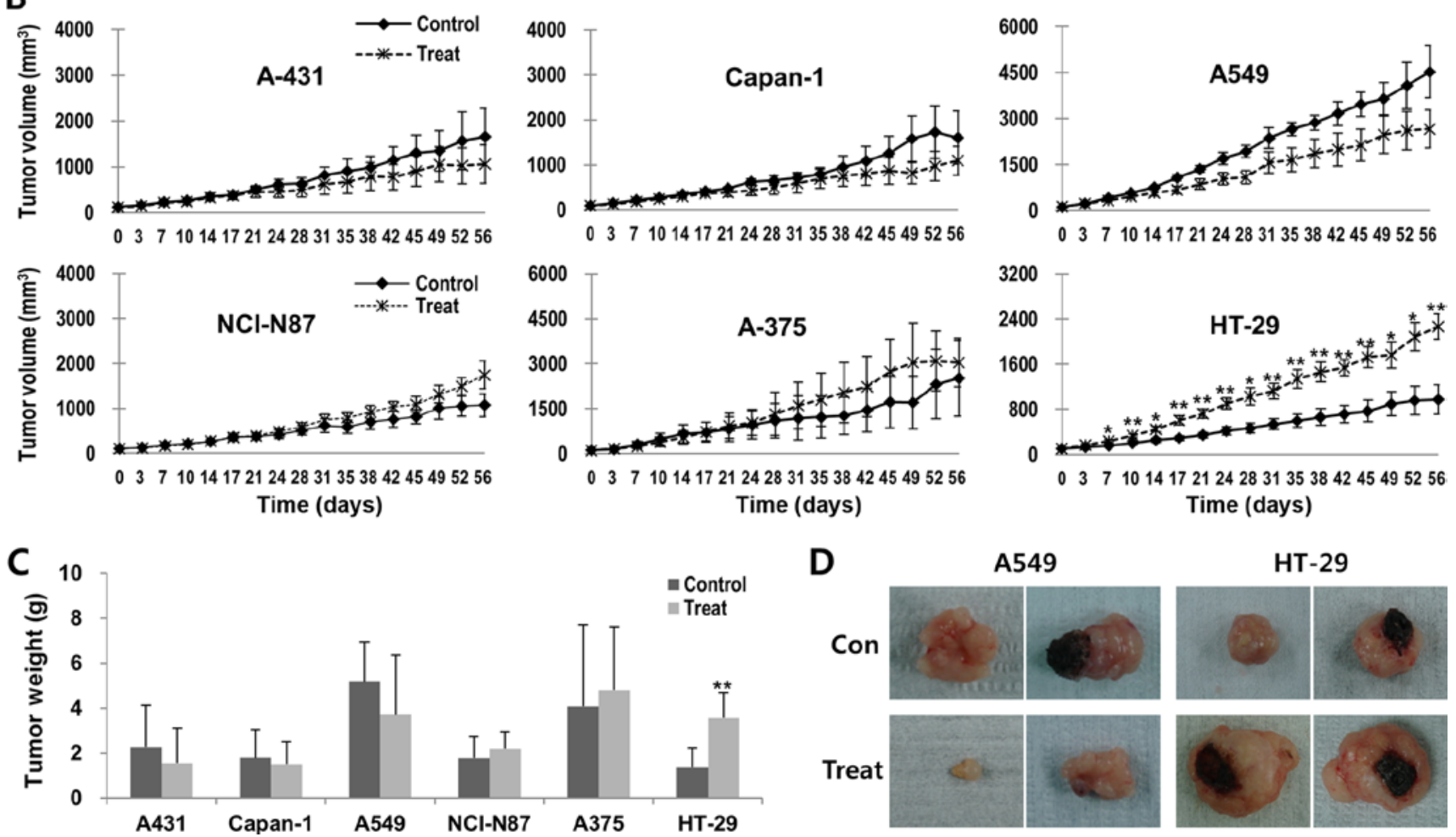

Figure 1. Effects of hATMSCs on the growth of various types of tumors in in vivo xenograft models using BALB/c-nude mice. (A) Flow cytometric characterization of hATMSCs. hATMSCs were labeled with antibodies specific for hATMSC surface antigens. The number in parenthesis indicates the percentage of surface marker-positive cells. (B) Changes in tumor volume following hATMSC injection in the various tumor models. Data are expressed as means $\pm \mathrm{SE}$ ( $\mathrm{p}<0.05$ and $\left.{ }^{* *} \mathrm{p}<0.01\right)$. (C) Tumor weights at 8 weeks following hATMSC injection. Data are expressed as means $\pm \mathrm{SD}\left({ }^{* *} \mathrm{p}<0.01\right)$. (D) Representative images of tumor growth. hATMSCs, human adipose tissue-derived mesenchymal stem cells.

the quantity was determined by the ND-1000 spectrophotometer (Thermo Scientific, Wilmington, DE, USA). Affymetrix GeneChip ${ }^{\circledR}$ Human Gene 2.0 ST Array (Affymetrix, Santa Clara, CA, USA) was used to analyze differential gene expression profiles as previously described (27). In order to determine whether genes were differentially expressed among the groups, the genes that showed $>1.5$-fold difference between the average signal values of the control and test groups were selected. Additionally, genes with a p-value $<0.05$ were extracted by Student's t-test (two-tailed, unpaired). After significant genes were identified, the web-based tool Database for Annotation, Visualization and Integrated Discovery (DAVID) was used to perform the biological interpretation of the differentially expressed genes. The genes were classified based on the information of gene function in Gene Ontology (GO) (http://david. abc.ncifcrf.gov/home.jsp).

Flow cytometric analysis. Cancer cells were analyzed by a flow cytometer (FACSCalibur; Becton-Dickinson, San Jose, CA, USA) to assess levels of proliferation, apoptosis and $\mathrm{NF}-\kappa \mathrm{B}$ expression. Apoptosis and proliferation were evaluated using Annexin V-FITC Early Apoptosis Detection kit (Cell Signaling Technology) and BrdU Flow kit (BD Pharmingen), respectively, according to the manufacturer's instructions. Harvested tumor cells were centrifuged, resuspended in PBS and fixed in 2-4\% formaldehyde. Phospho-NF- $\mathrm{kB}$ p65-Alexa Fluor 647 conjugate (Cell Signaling Technology) antibody was used for NF- $\mathrm{KB}$ analysis.

Statistical analysis. Statistical analysis of the results was performed using one-way ANOVA (SPSS, Inc., Chicago, IL, USA). p-values of $<0.05$ were considered to indicate statistically significant results. If the variance was significant, the data were analyzed by the multiple comparison procedure of Dunnett's test.

\section{Results}

Effects of the hATMSCs on the growth of various types of tumors in vivo xenograft models. For immunophenotypic characterization of the hATMSCs, surface marker expression was examined by flow cytometry. The hATMSCs expressed high levels of MSC markers CD73 and CD90, whereas the hATMSCs were negative for cell adhesion molecule marker CD31 and hematopoietic stem cell markers CD34 and CD45 (Fig. 1A). 

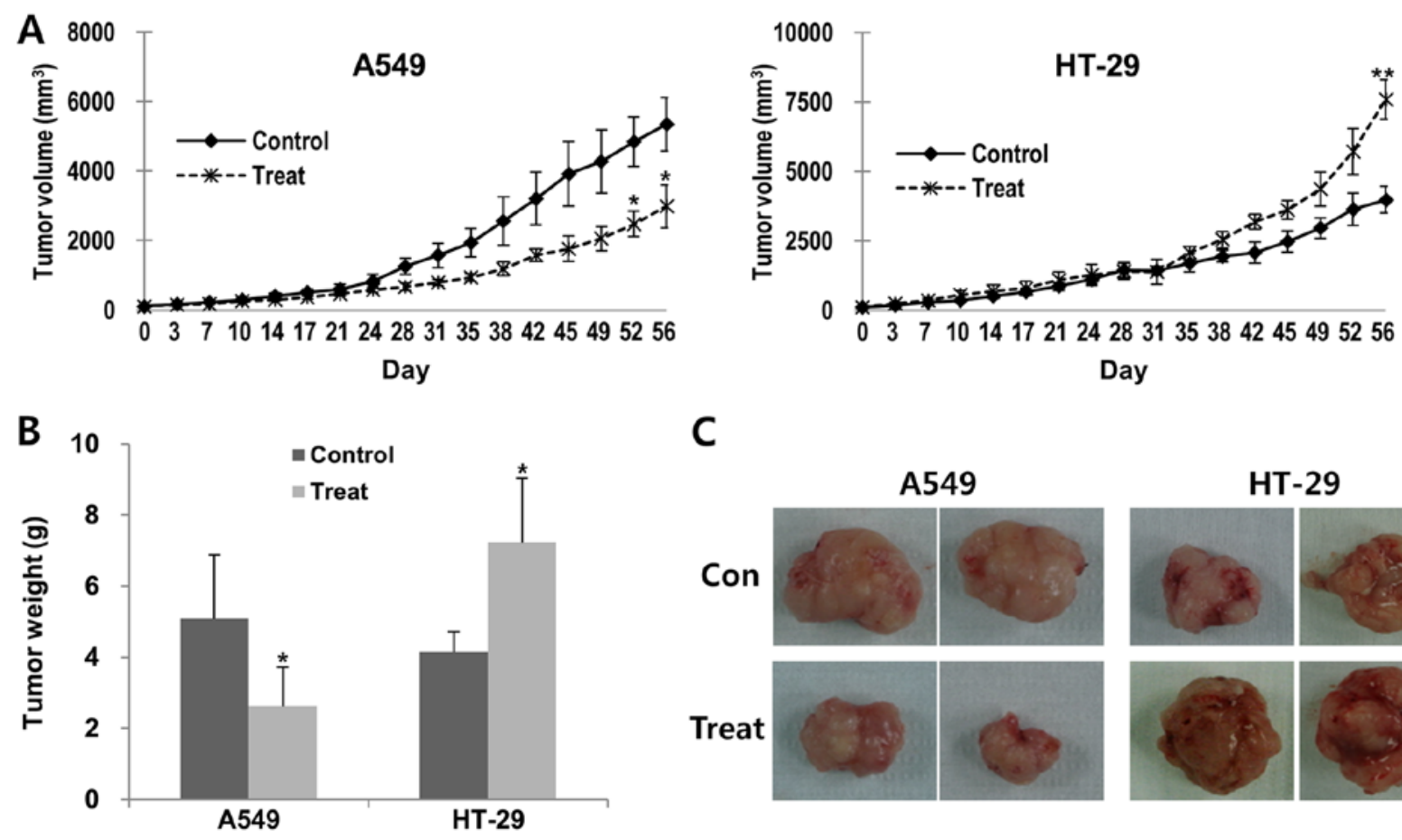

C
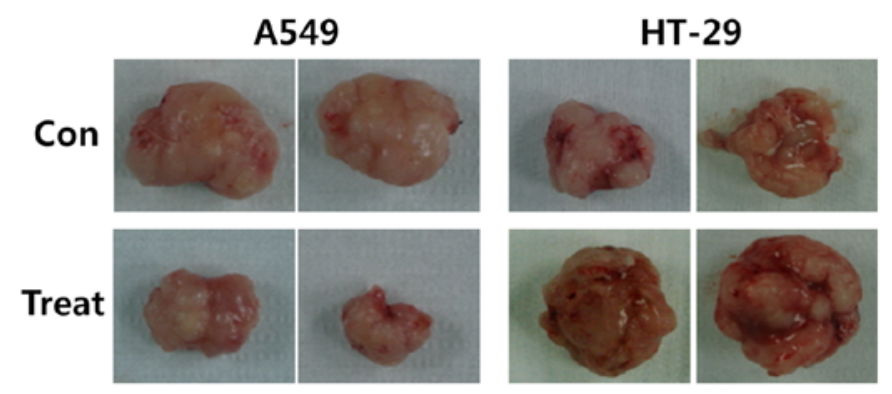

Figure 2. Effects of hATMSCs on the growth of A549 and HT-29 tumors in in vivo xenograft models using hairless SCID mice. (A) Changes in the tumor volume following hATMSC injection in two tumor models. Data are expressed as means $\pm \mathrm{SE}\left({ }^{*} \mathrm{p}<0.05\right.$ and $\left.{ }^{* *} \mathrm{p}<0.01\right)$. (B) Tumor weights at 8 weeks following hATMSC injection. Data are expressed as means \pm SD ("p<0.05). (C) Representative images of tumor growth. hATMSCs, human adipose tissue-derived mesenchymal stem cells.

In Korea, the stomach, colon and lung have been reported to be the five leading primary sites of cancer both in males and females in 2013 (28). In addition to xenograft models for these cancers, three well-known xenografts, A-375 melanoma, skin squamous cell carcinoma A-431 and Capan-1 pancreatic xenografts (29-31), were used in order to investigate the dual effects of the hATMSCs on tumor growth. The tumor size was measured for 8 weeks after the first subcutaneous hATMSC injection in the BALB/c-nude mice subcutaneously inoculated with the cancer cells. The rates of growth of the A431, Capan-1 and A549 tumors were reduced in the hATMSC-injected groups compared with the respective control groups, although the differences did not reach statistical significance (Fig. 1B). In contrast, NCI-N87 and A375 tumors showed the tendency toward increased volume in the hATMSC-injected groups in comparison to the respective control groups. Particularly, the tumor weight of the HT-29 tumors in the hATMSC group was significantly greater than that in the control group. The differences in tumor weights between the hATMSC and the respective control groups showed consistent patterns with the changes in tumor volume (Fig. 1C and D).

Based on the changes in mean volumes and weights by the hATMSC injection in the BALB/c-nude mice, we selected the A549 and the HT-29 tumors for additional in vivo experiments using hairless SCID mice, and confirmed similar dual effects of the hATMSCs in these two types of tumors. The volume and weight of the A549 tumors were significantly reduced in the hATMSC group compared with the parameters in the control group, whereas the tumor volume and weight of the hATMSC-treated HT-29 tumors were significantly greater than the control group (Fig. 2).
Co-culture effect of the hATMSCs on the viability of cancer cell lines A549 and HT-29 in vitro. Tian et al (8) reported opposite effects of MSCs in vivo and in vitro; human BM-MSCs exerted a tumor inhibitory effect in vitro, yet surprisingly had a promoting effect on tumor growth in vivo. To confirm the effects of the hATMSCs on tumor growth in vivo, the A549 and HT-29 cells were co-cultured with the hATMSCs at different ratios of 10:0.5, 10:1 and 10:2 (Fig. 3A). The direct co-culture of the A549 cells with the hATMSCs at the ratios of 10:1 and 10:2 attenuated the proliferation rates of the cells by 9.78 and $19.82 \%$, respectively, compared to the control group (10:0), whereas the direct co-culture of the HT-29 cells with the hATMSCs at the ratios of 10:1 and 10:2 increased the proliferation rates of the cells by 17.22 and $29.78 \%$, respectively, compared to the control group (10:0). This probably resulted from the proliferation rates of the cancer cells changed by the hATMSCs. However, further evidence that excluded the confounding effects associated with changes in the proliferation rates of the hATMSCs by the cancer cells was needed. Thus, indirect co-culture of the cancer cells with the hATMSCs using cell inserts was conducted in order to prevent cell-to-cell contact. The same trends were observed in the indirect co-culture. The proliferation rates of the A549 cells were reduced by 9.72 and $18.57 \%$, respectively, whereas those of the HT-29 cells were increased by 19.90 and $25.79 \%$, respectively, compared to the control group (10:0).

Co-culture effect of the hATMSCs on the proliferation and apoptosis of cancer cells. The proliferation of the cancer cells indirectly co-cultured with the hATMSCs was measured by BrdU staining and flow cytometry. The percentage of 
A

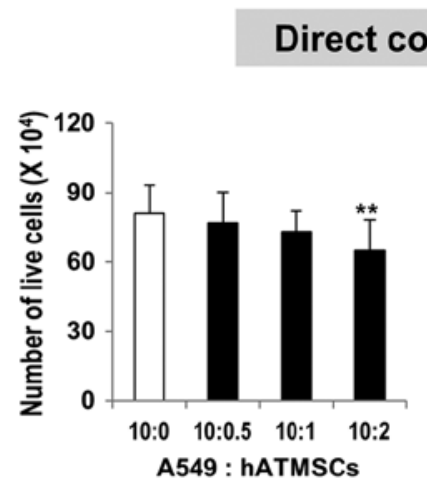

\section{Direct co-culture}

Indirect co-culture
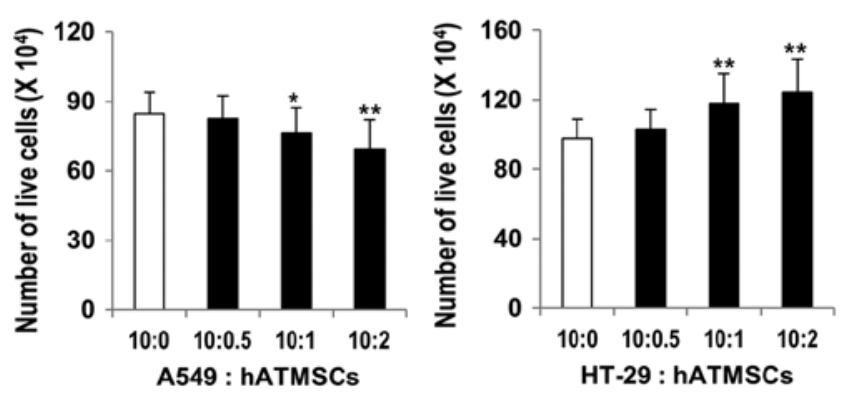
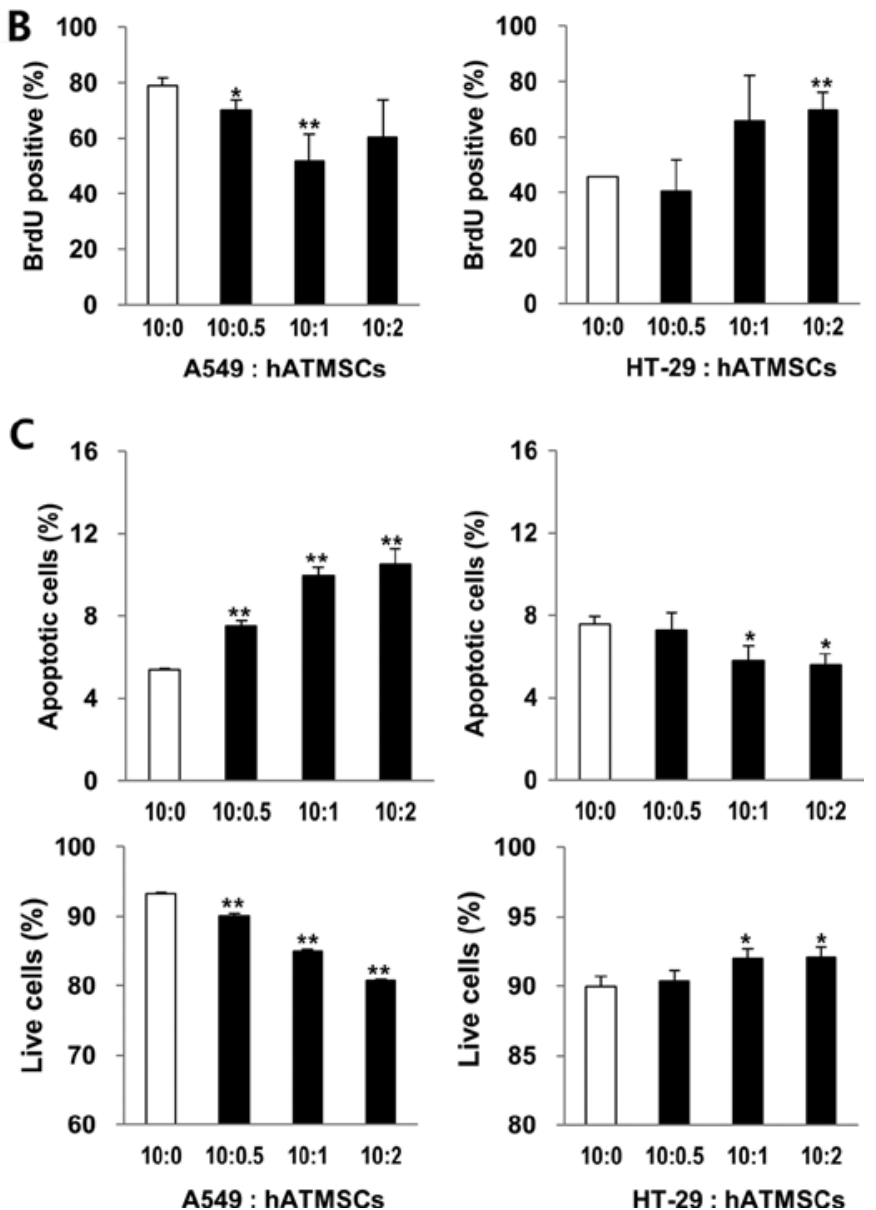

Figure 3. Co-culture effects of hATMSCs on the A549 and HT-29 tumor cells in vitro. (A) The percentage of live cells following direct or indirect coculture of tumor cells with hATMSCs. (B) BrdU staining and flow cytometry for the proliferation rates in the indirect co-culture of tumor cells with hATMSCs. (C) Annexin V/PI double staining and flow cytometry for the apoptotic rates in the indirect co-culture of tumor cells with hATMSCs. Apoptotic cells include Annexin $\mathrm{V}^{+} / \mathrm{PI}^{+}$cells and Annexin $\mathrm{V}^{+} / \mathrm{PI}^{-}$cells. Data are expressed as the means \pm SD $\left({ }^{*} \mathrm{p}<0.05\right.$ and $\left.{ }^{* *} \mathrm{p}<0.01\right)$. hATMSCs, human adipose tissue-derived mesenchymal stem cells.

BrdU-positive A549 cells was reduced by the hATMSC co-culture by 34 and $23 \%$ at the ratios of $10: 1$ and 10:2, respectively, whereas there was a significant induction of the percentage of BrdU-positive HT-29 cells co-cultured with the hATMSCs at the ratios of 10:2 (Fig. 3B). The apoptotic rates of the cancer cells co-cultured with the hATMSCs were analyzed by Annexin V/PI double staining and flow cytometry. While the percentage of live A549 cells was significantly diminished by co-culture with the hATMSCs, the percentage of apoptotic A549 cells was elevated by 40,85 and $95 \%$ at the ratios of 10:0.5, 10:1 and 10:2, respectively (Fig. 3C). However, the hATMSCs had opposite effects on the HT-29 cells; there was an increase in live HT-29 cells and a decrease in apoptotic HT-29 cells of 23 and $26 \%$ at the ratios of 10:1 and 10:2, respectively. Collectively, the hATMSCs inhibited the proliferation, yet elevated the apoptosis in the A549 cancer cells, whereas it promoted the proliferation and reduced apoptosis in the HT-29 cancer cells.

Global differences in gene expression in the xenograft tumors in the presence or absence of the hATMSCs. In the microarray experiment with the A549 tumors of the hairless SCID mice, 4,022 probe sets were used to identify significant differences between the hATMSC and the control group in regards to expression levels of genes (fold-change $>1.5$ ) (Fig. 4A and B). Particularly, we found that the expression levels of 1,725 probes were increased and those of 2,297 probes were decreased in the hATMSC group. In contrast, in the microarray experiment with the HT-29 tumors of the hairless SCID mice, 164 probes were found expressed more highly in the hATMSC group, whereas 135 probes were found to be more lowly expressed in the hATMSC group. Based on more stringent statistical criteria (fold-change $>1.5$ and $\mathrm{p}<0.05$ ), 568 genes were expressed at a higher level and 1,191 genes were expressed at a lower level in the hATMSC group compared with the control group in the A549 tumors (Table I). In contrast, 9 genes were expressed at a higher level and 14 genes were expressed at a lower level in the hATMSC group when compared with the control group in the HT-29 tumors (Table II).

Among the genes differentially expressed in the xenograft tumors after the hATMSC injection, histone cluster 1, H2aj (HIST1H2AJ) was expressed in direct proportion to the xenograft tumor size. In other words, it was expressed at lower level in the A549 tumors and was expressed at a higher level in the HT-29 tumors after the hATMSC injection in comparison to the respective control groups. In addition, neuropeptide Y receptor Y4 (NPY4R) and LOC100505817 were expressed in inverse proportion to the xenograft tumor 
A

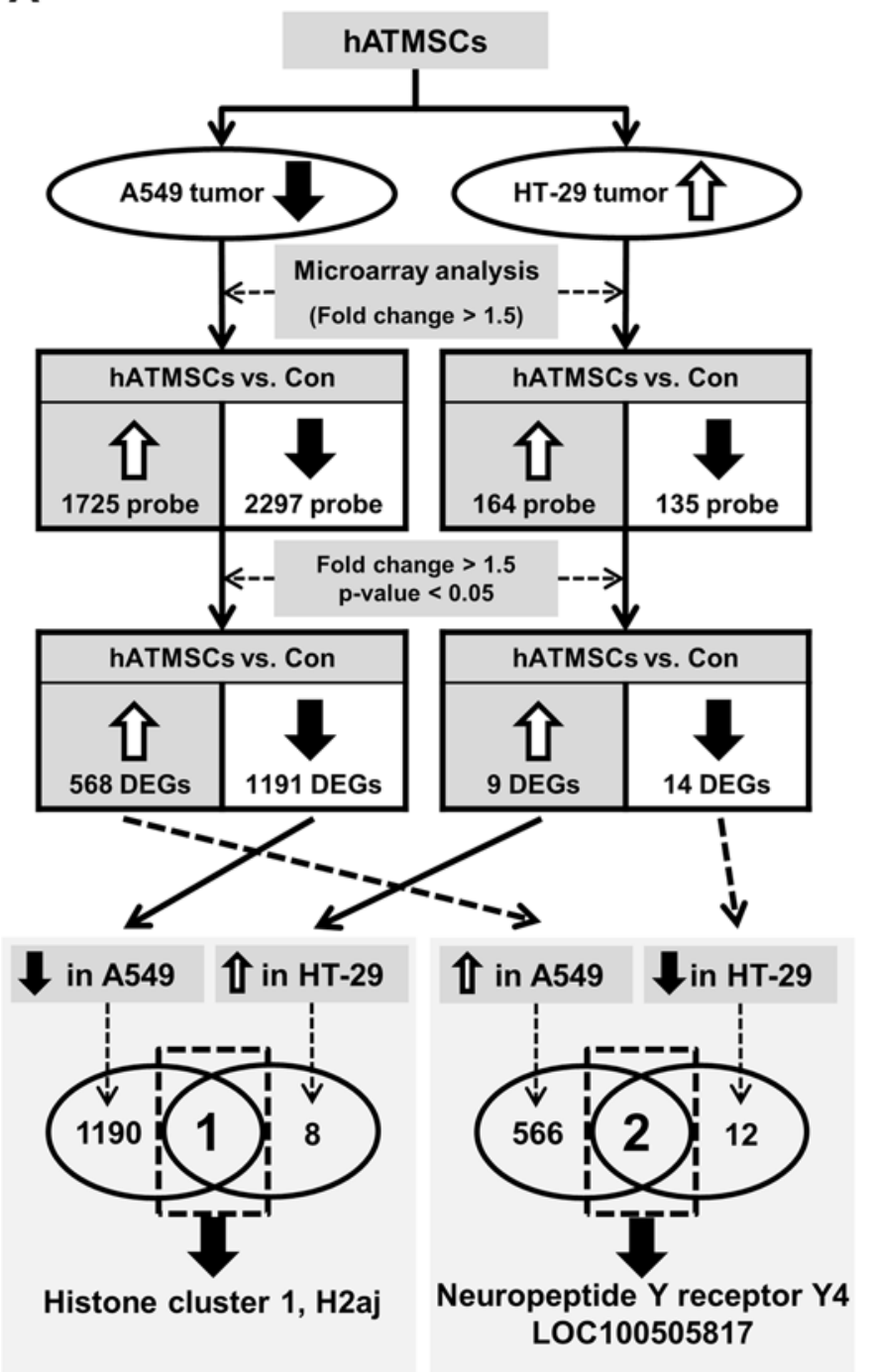

B

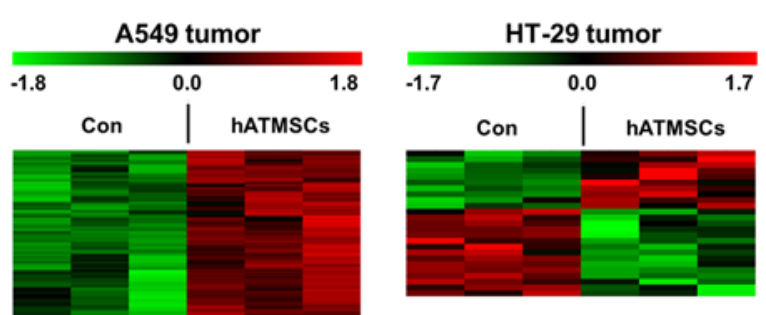

C

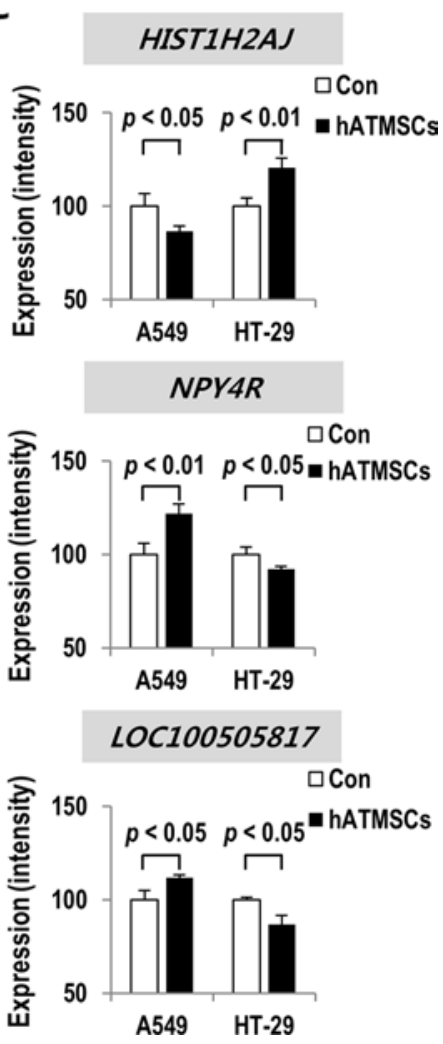

Figure 4. Identification of genes exhibiting differential expression levels following hATMSC injection in the A549 and HT-29 tumor models using hairless SCID mice. (A) Genes differentially expressed (DEGs) in the microarray analysis among the groups. (B) 'Heat-map' representation of the genes differentially expressed (fold-change $>1.5$ and $\mathrm{p}<0.05$ ). (C) The differences in HISTIH2AJ, NPY4R and LOC100505817 expression (intensity) in the microarray analysis among the groups. hATMSCs, human adipose tissue-derived mesenchymal stem cells.

size. They were expressed at a higher level in the A549 tumors and were expressed at a lower level in the HT-29 tumors after the hATMSC injection in comparison to the respective control groups (Fig. 4A and C).

Functional classification of genes showing differential expression in the hATMSC-treated xenograft tumors. In order to identify the biological function of the genes differentially expressed following the hATMSC injection in the A549 and HT-29 tumor models using hairless SCID mice, GO analysis was performed. The statistically significant categories of GO terms $[\mathrm{p}<0.01$; false discovery rate $(\mathrm{FDR})<0.05]$ are shown in Table III. No enriched GO term was altered following treatment with the hATMSCs in the HT-29 tumors, whereas the genes involved in biological processes, such as 'Regulation of growth' and 'Regulation of cell growth' were upregulated in the hATMSC-treated A549 tumors. The genes involved in biological processes, such as 'Nucleosome assembly', 'Nucleosome organization', 'Protein-DNA complex assembly',
'Chromatin assembly or disassembly', 'Cell-cell adhesion' and 'Regulation of transcription (DNA-dependent)' were downregulated in the hATMSC-treated A549 tumors.

Effects of the hATMSCs on the phosphorylation of NF- $\kappa B$ p65 in the A549 and HT-29 tumors in vivo and in vitro. The proteins extracted from the xenograft tumor masses of the hairless SCID mice were analyzed by western blot analysis to investigate whether there is a relationship between certain cell signaling pathways and the hATMSC-associated modulation of tumor growth. Among several proteins related to cell signaling pathways, the expression level of phosphorylated NF- $\kappa$ B p 65 was reduced by $31 \%$ in the hATMSC-injected A549 tumor, whereas it was increased by $77 \%$ in the hATMSCinjected HT-29 tumors (Fig. 5A and B). The levels of other cell signaling-related proteins, such as p-JAK3 and p-STAT3, were not affected by the hATMSCs in the A549 and HT-29 tumors, and the $\beta$-catenin protein level was elevated by the hATMSCs in the HT-29 tumors, yet not affected in the A549 tumors, 
Table I. Top 30 genes showing differential expression in the hATMSC-treated A549 tumors ranked by fold-change.

\begin{tabular}{|c|c|c|c|}
\hline Probe set & Gene & Gene description & Fold-chang \\
\hline \multicolumn{4}{|c|}{ Genes expressed at a higher level in A549 tumors after hATMSC injection ( $\mathrm{p}<0.05$, fold-change $>1.5)$} \\
\hline 16863393 & $I G F L 2$ & IGF-like family member 2 & 3.68 \\
\hline 16976821 & $P P B P$ & Pro-platelet basic protein [chemokine (C-X-C motif) ligand 7] & 3.18 \\
\hline 17061759 & NRCAM & Neuronal cell adhesion molecule & 2.77 \\
\hline 16852322 & MAPK4 & Mitogen-activated protein kinase 4 & 2.47 \\
\hline 16873513 & LOC400706 & Uncharacterized LOC400706 & 2.46 \\
\hline 17083433 & IL33 & Interleukin 33 & 2.45 \\
\hline 16745990 & $\operatorname{miR3167}$ & MicroRNA 3167 & 2.17 \\
\hline 16909319 & DNER & $\Delta /$ notch-like EGF repeat containing & 2.07 \\
\hline 17022996 & ROS1 & c-ros oncogene 1 , receptor tyrosine kinase & 1.97 \\
\hline 16713760 & HNRNPAIP33 & Heterogeneous nuclear ribonucleoprotein A1 pseudogene 33 & 1.97 \\
\hline 16733325 & KIRREL3-AS2 & KIRREL3 antisense RNA 2 & 1.87 \\
\hline 16704464 & NPY4R & Neuropeptide Y receptor Y4 & 1.86 \\
\hline 16742086 & $P G M 2 L 1$ & Phosphoglucomutase 2 -like 1 & 1.85 \\
\hline 16710126 & HTRAl & HtrA serine peptidase 1 & 1.79 \\
\hline 17012392 & RSPO3 & R-spondin 3 & 1.69 \\
\hline 16737590 & SYT13 & Synaptotagmin XIII & 1.66 \\
\hline 16997795 & $V C A N-A S 1$ & VCAN antisense RNA 1 & 1.66 \\
\hline 16852849 & SERPINB11 & $\begin{array}{l}\text { Serpin peptidase inhibitor, clade B (ovalbumin), } \\
\text { member } 11 \text { (gene/pseudogene) }\end{array}$ & 1.63 \\
\hline 16958382 & MUC13 & Mucin 13 , cell surface associated & 1.62 \\
\hline 16713762 & ANXA8L1 & Annexin A8-like 1 & 1.61 \\
\hline 16851950 & $\operatorname{miR} 3975$ & MicroRNA 3975 & 1.59 \\
\hline 17060820 & MUC12 & Mucin 12 , cell surface associated & 1.58 \\
\hline 16705934 & CHST3 & Carbohydrate (chondroitin 6) sulfotransferase 3 & 1.58 \\
\hline 16677556 & $T G F B 2$ & Transforming growth factor, $\beta 2$ & 1.57 \\
\hline 16704614 & ANXA8 & Annexin A8 & 1.55 \\
\hline 16704516 & ANXA8L2 & Annexin A8-like 2 & 1.55 \\
\hline 16957304 & $Z B E D 2$ & Zinc finger, BED-type containing 2 & 1.54 \\
\hline 16960922 & RARRES1 & Retinoic acid receptor responder (tazarotene induced) 1 & 1.51 \\
\hline 17067696 & $N R G 1$ & Neuregulin 1 & 1.50 \\
\hline 16697674 & LINC00862 & Long intergenic non-protein coding RNA 862 & 1.50 \\
\hline
\end{tabular}

Genes expressed at a lower level in A549 tumors after hATMSC injection $(\mathrm{p}<0.05$, fold-change $>1.5)$

\begin{tabular}{|c|c|c|c|}
\hline 16971272 & EDNRA & Endothelin receptor type A & -4.75 \\
\hline 17113448 & ILI3RA2 & Interleukin 13 receptor, $\alpha 2$ & -4.58 \\
\hline 17112149 & $X I S T$ & $\mathrm{X}$ inactive specific transcript (non-protein coding) & -4.44 \\
\hline 16965377 & SLIT2 & Slit homolog 2 (Drosophila) & -4.32 \\
\hline 16977241 & NAA11 & $\mathrm{N}(\alpha)$-acetyltransferase 11 , NatA catalytic subunit & -4.22 \\
\hline 17055447 & MEOX2 & Mesenchyme homeobox 2 & -4.11 \\
\hline 17101570 & LOC100133123 & Uncharacterized LOC100133123 & -4.05 \\
\hline 16870838 & ZNF208 & Zinc finger protein 208 & -4.01 \\
\hline 17001578 & $P D G F R B$ & Platelet-derived growth factor receptor, $\beta$ polypeptide & -3.93 \\
\hline 16732840 & OR8G2 & Olfactory receptor, family 8 , subfamily $\mathrm{G}$, member 2 & -3.91 \\
\hline 16736764 & MUC15 & Mucin 15 , cell surface associated & -3.86 \\
\hline 16870821 & ZNF100 & Zinc finger protein 100 & -3.83 \\
\hline 16909828 & COL6A3 & Collagen, type VI, $\alpha 3$ & -3.72 \\
\hline 16997383 & $F 2 R L 2$ & Coagulation factor II (thrombin) receptor-like 2 & -3.68 \\
\hline 16979875 & PCDH18 & Protocadherin 18 & -3.62 \\
\hline 17058002 & LOC650226 & Ankyrin repeat domain 26 pseudogene & -3.56 \\
\hline 16942958 & ЕРНA3 & EPH receptor A3 & -3.52 \\
\hline 17108003 & $B G N$ & Biglycan & -3.51 \\
\hline
\end{tabular}


Table I. Continued.

\begin{tabular}{llll}
\hline Probe set & \multicolumn{1}{c}{ Gene } & \multicolumn{1}{c}{ Gene description } & Fold-change $^{\mathrm{a}}$ \\
\hline 16852966 & CCDC102B & Coiled-coil domain containing 102B & -3.51 \\
17097661 & TNC & Tenascin C & -3.45 \\
17078870 & $M M P 16$ & Matrix metallopeptidase 16 (membrane-inserted) & -3.32 \\
16772888 & RNU6-52P & RNA, U6 small nuclear 52, pseudogene \\
16870854 & ZNF676 & Zinc finger protein 676 \\
16888610 & COL3A1 & Collagen, type III, $\alpha 1$ & -3.29 \\
16923842 & COL6A1 & Collagen, type VI, $\alpha 1$ & -3.21 \\
16666509 & IFI44 & Interferon-induced protein 44 \\
17107835 & MAGEA4 & Melanoma antigen family A, 4 \\
17107867 & MAGEA6 & Melanoma antigen family A, 6 \\
16673075 & DDR2 & Discoidin domain receptor tyrosine kinase 2 & -3.13 \\
16885596 & POTEJ & POTE ankyrin domain family, member J & -3.08 \\
\hline
\end{tabular}

${ }^{a}$ Each value represents the fold-change (in $\log _{2}$ value) vs. the control group. hATMSCs, human adipose tissue-derived mesenchymal stem cells .

Table II. Genes showing differential expression in the hATMSC-treated HT-29 tumors ranked by fold-change.

\begin{tabular}{|c|c|c|c|}
\hline Probe set & Gene & Gene description & Fold-chan \\
\hline \multicolumn{4}{|c|}{ Genes expressed at a higher level in the HT-29 tumors after hATMSC injection $(\mathrm{p}<0.05$, fold-change $>1.5)$} \\
\hline 16703429 & RNA5SP307 & RNA, 5S ribosomal pseudogene 307 & 0.97 \\
\hline 17016490 & HIST1H2AJ & Histone cluster $1, \mathrm{H} 2 \mathrm{aj}$ & 0.91 \\
\hline 16761541 & PRB4 & Proline-rich protein BstNI subfamily 4 & 0.85 \\
\hline 17063776 & TRBV6-8 & T cell receptor $\beta$ variable $6-8$ & 0.77 \\
\hline 16854216 & miRl33Al & MicroRNA 133a-1 & 0.74 \\
\hline 16943350 & GPR128 & G protein-coupled receptor 128 & 0.67 \\
\hline 17117463 & LOC 100509635 & Uncharacterized LOC100509635 & 0.64 \\
\hline 17063800 & $T R B V 7-4$ & T cell receptor $\beta$ variable $7-4$ (gene/pseudogene) & 0.63 \\
\hline 16904484 & SNORA7OF & Small nucleolar RNA, H/ACA box 70F & 0.61 \\
\hline
\end{tabular}

Genes expressed at a lower level in the HT-29 tumors after hATMSC injection ( $<<0.05$, fold-change $>1.5)$

$\begin{array}{llll}16691574 & \text { RNA5SP56 } & \text { RNA, 5S ribosomal pseudogene 56 } & -1.05 \\ 16798050 & \text { PAR-SN } & \text { Paternally expressed transcript PAR-SN } & -0.74 \\ 17114740 & \text { SPANXN3 } & \text { SPANX family, member N3 } & -0.74 \\ 16798146 & \text { SNORD116-5 } & \text { Small nucleolar RNA, C/D box 116-5 } & -0.73 \\ 16798150 & \text { SNORD116-5 } & \text { Small nucleolar RNA, C/D box 116-5 } & -0.73 \\ 16734339 & \text { miR4298 } & \text { MicroRNA 4298 } & -0.72 \\ 16716369 & \text { miR4679-2 } & \text { MicroRNA 4679-2 } & -0.70 \\ 16743207 & \text { TRIM51EP } & \text { Tripartite motif-containing 51E, pseudogene } & -0.68 \\ 16853028 & \text { LOC100505817 } & \text { Uncharacterized LOC100505817 } & -0.64 \\ 16767367 & \text { miR3913-1 } & \text { MicroRNA 3913-1 } & -0.63 \\ 17114772 & \text { miR891B } & \text { MicroRNA 891b } & -0.60 \\ 16696120 & \text { DPT } & \text { Dermatopontin } & -0.59 \\ 17096623 & \text { BAAT } & \text { Bile acid CoA: amino acid N-acyltransferase } & -0.59 \\ 16704464 & \text { NPY4R } & \text { (glycine N-choloyltransferase) } & -0.59\end{array}$

${ }^{\mathrm{a} E a c h}$ value represents the fold-change (in $\log _{2}$ value) vs. the control group. hATMSCs, human adipose tissue-derived mesenchymal stem cells. 
Table III. GO terms associated with upregulated and downregulated trends in the hATMSC-treated A549 tumors (p<0.01, FDR<0.05).

\begin{tabular}{|c|c|c|c|c|c|}
\hline GO ID & Biological process term & Gene count & P-value & Benjamini & FDR \\
\hline \multicolumn{6}{|c|}{ Upregulated trend } \\
\hline GO:0040008 & Regulation of growth & 24 & $1.19 \mathrm{E}-05$ & 0.0258 & 0.021 \\
\hline GO:0001558 & Regulation of cell growth & 17 & $2.37 \mathrm{E}-05$ & 0.0256 & 0.041 \\
\hline \multicolumn{6}{|c|}{ Downregulated trend } \\
\hline GO:0006334 & Nucleosome assembly & 24 & $9.31 \mathrm{E}-11$ & $2.44 \mathrm{E}-07$ & $1.65 \mathrm{E}-07$ \\
\hline GO:0034728 & Nucleosome organization & 25 & $1.41 \mathrm{E}-10$ & $1.85 \mathrm{E}-07$ & $2.51 \mathrm{E}-07$ \\
\hline GO:0031497 & Chromatin assembly & 24 & $2.02 \mathrm{E}-10$ & $1.77 \mathrm{E}-07$ & $3.58 \mathrm{E}-07$ \\
\hline GO:0065004 & Protein-DNA complex assembly & 24 & $5.37 \mathrm{E}-10$ & $3.53 \mathrm{E}-07$ & $9.52 \mathrm{E}-07$ \\
\hline GO:0006323 & DNA packaging & 27 & $8.47 \mathrm{E}-10$ & $4.45 \mathrm{E}-07$ & $1.50 \mathrm{E}-06$ \\
\hline GO:0006333 & Chromatin assembly or disassembly & 28 & $1.15 \mathrm{E}-09$ & $5.02 \mathrm{E}-07$ & $2.03 \mathrm{E}-06$ \\
\hline GO:0006350 & Transcription & 175 & $9.61 \mathrm{E}-09$ & $3.60 \mathrm{E}-06$ & $1.70 \mathrm{E}-05$ \\
\hline GO:0006355 & Regulation of transcription, DNA-dependent & 151 & $3.65 \mathrm{E}-08$ & $1.20 \mathrm{E}-05$ & $6.47 \mathrm{E}-05$ \\
\hline GO:0051252 & Regulation of RNA metabolic process & 153 & $5.05 \mathrm{E}-08$ & $1.47 \mathrm{E}-05$ & $8.96 \mathrm{E}-05$ \\
\hline GO:0034621 & $\begin{array}{l}\text { Cellular macromolecular complex } \\
\text { subunit organization }\end{array}$ & 45 & $5.14 \mathrm{E}-07$ & $1.35 \mathrm{E}-04$ & $9.12 \mathrm{E}-04$ \\
\hline GO:0034622 & Cellular macromolecular complex assembly & 41 & $1.01 \mathrm{E}-06$ & $2.41 \mathrm{E}-04$ & 0.002 \\
\hline GO:0006325 & Chromatin organization & 46 & $1.01 \mathrm{E}-06$ & $2.22 \mathrm{E}-04$ & 0.002 \\
\hline GO:0016339 & Calcium-dependent cell-cell adhesion & 10 & $1.91 \mathrm{E}-06$ & $3.85 \mathrm{E}-04$ & 0.003 \\
\hline GO:0045449 & Regulation of transcription & 193 & $6.37 \mathrm{E}-06$ & 0.0012 & 0.011 \\
\hline GO:0051276 & Chromosome organization & 52 & $7.69 \mathrm{E}-06$ & 0.0013 & 0.014 \\
\hline
\end{tabular}

GO, Gene Ontology; FDR, false discovery rate.

providing a possible correlation between the $\mathrm{NF}-\kappa \mathrm{B}$ pathway and hATMSC-related tumor modulation, at least in the A549 and the HT-29 tumors.

Changes in phosphorylated NF- $\mathrm{B}$ p65 in the tumor masses in vivo were confirmed using flow cytometric analysis in the cancer cells indirectly co-cultured with the hATMSCs, which revealed significant reductions in phosphorylated $\mathrm{NF}-\kappa \mathrm{B}$ p 65 by 12,25 and $32 \%$ in the co-culture of the A549 cancer cells with the hATMSCs at the ratios of 10:0.5, 10:1 and 10:2, respectively, compared with the control (10:0) (Fig. 5C). However, there was an inverse effect in the HT-29 cancer cells, showing a profound increase in phosphorylated $\mathrm{NF}-\kappa \mathrm{B}$ p65 by $15 \%$ in the co-culture of HT-29 cancer cells with the hATMSCs at the ratio of 10:2.

\section{Discussion}

In the present study, we found conflicting results concerning the effects of the hATMSCs on tumor growth, particularly in the A549 and HT-29 tumors which were suppressed and supported, respectively, by the hATMSCs. It is possible that the dual effect of MSCs can be dependent on tumor type, at least partially, although these two cell lines do not represent the types of cancer that they are derived from. Thus, further analysis is needed to verify the actual factors in different microenvironment induced by different cancer cells rather than attempting to propose the type of tumor as the reason.

A recent study showed that direct cell-to-cell interaction between cancer cells and MSCs is responsible for the effects of MSCs on tumor growth (32). Although we also observed this result when hATMSCs were directly injected at the tumor site in the xenograft tumor models in vivo, our hypothesis is that this effect of hATMSCs on tumor growth could be indirect according to the results of previous studies $(14,33)$. The hATMSCs showed dual effects such as a strong inhibitory effect on the A549 cancer cell viability and a dramatic promoting effect on the HT-29 cancer cell viability in vitro. In particular, in consistent with a study by Fierro et al (34), the hATMSCs showed a similar impact on cell viability between direct and indirect co-culture in our experiments using in vitro co-culture systems, indicating that the hATMSCs affected tumor cell growth even without direct cell-to-cell contact possibly due to certain soluble factors in the conditioned medium released from the hATMSCs. Among the many MSC-related soluble factors, proangiogenic factors, such as vascular endothelial growth factor (34), fibroblast growth factor (35), and angiopoietin-1 (36), promote endothelial and smooth muscle migration and proliferation at the tumor site, facilitating angiogenesis. In addition, there are factors such as interleukin 6 and tumor necrosis factor $\alpha$ (37) that are produced by MSCs and have immunosuppressive effects and eventually tumor supporting effects. Karnoub et al (21) reported that MSC-secreted chemokine ligand 5 induced a transient pro-metastatic effect on breast cancer cells. Meanwhile, ATMSCs were found to inhibit the proliferation in primary leukemia cells by secreting DKK-1, which exhibits an inhibitory effect on $\beta$-catenin signaling $(15,24)$. Further studies are necessary to analyze 

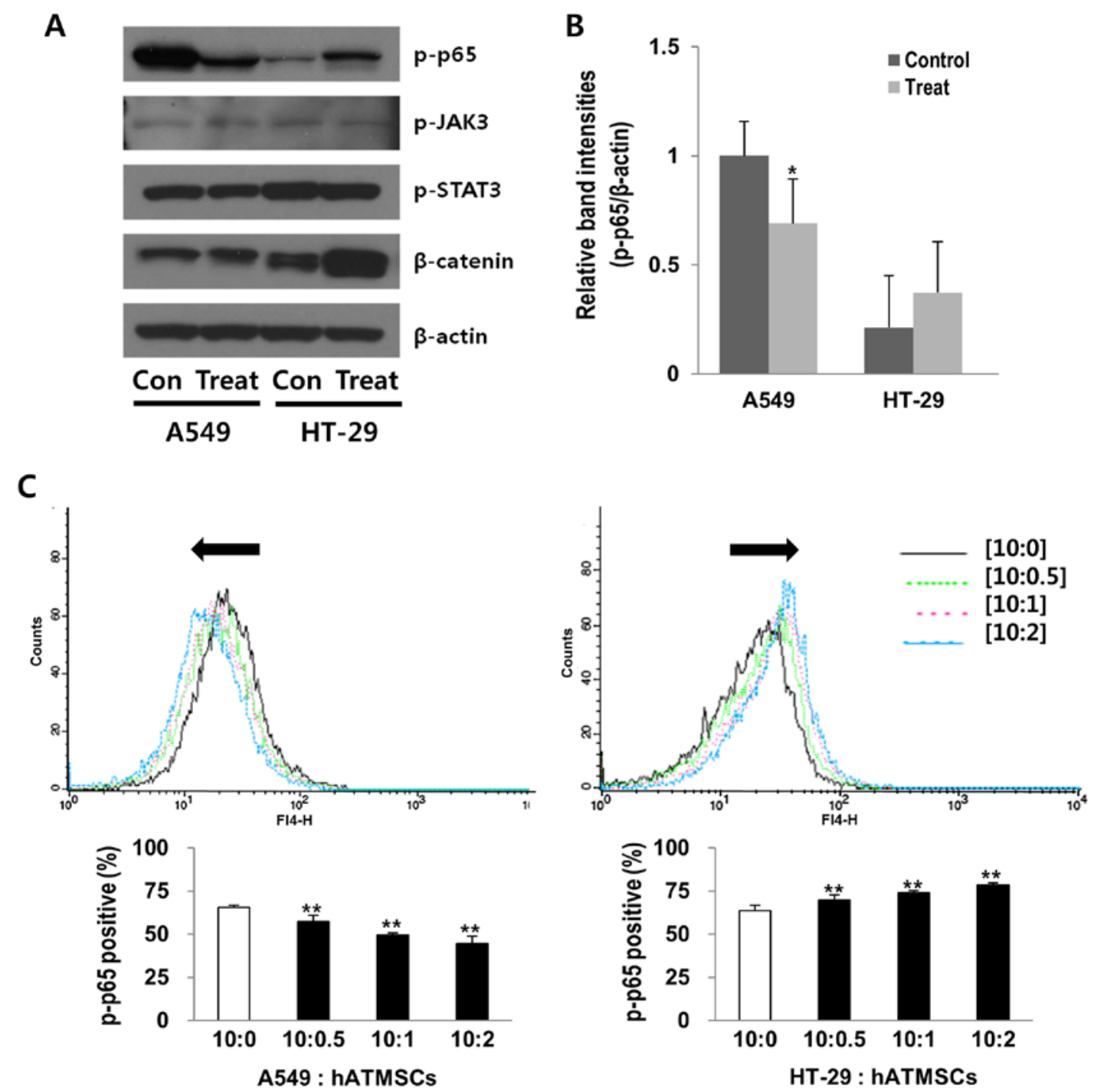

Figure 5. Effect of hATMSCs on phosphorylated NF- $\mathrm{KB}$ p65 in the A549 and HT-29 tumors in vivo and in vitro. (A) The expression levels of phosphorylated NF- $\mathrm{kB}$ p65, p-JAK3, p-STAT3, $\beta$-catenin and $\beta$-actin in A549 and HT-29 tumor masses of hairless SCID mice were detected by western blotting. (B) The mean of relative band intensities of phosphorylated NF-kB p65. (C) Flow cytometry for phosphorylated NF-kB p65 in A549 or HT-29 cells co-cultured with hATMSCs. Data are expressed as means $\pm \mathrm{SD}\left({ }^{*} \mathrm{p}<0.05\right.$ and $\left.{ }^{* *} \mathrm{p}<0.01\right)$. hATMSCs, human adipose tissue-derived mesenchymal stem cells.

which hATMSC-releasing factors contribute to the effect of hATMSCs on tumor growth.

The tumor growth was differentially mediated by hATMSCs between the A549 and the HT-29 tumors with in vivo xenograft models. For functional classification of the genes that were expressed differentially following treatment with the hATMSCs in the A549 and HT-29 tumors, GO and KEGG pathway analyses were performed. Noteworthy, 17 enriched GO categories were identified in the hATMSC-treated A549 tumors $(\mathrm{p}<0.01, \mathrm{FDR}<0.05)$, whereas no GO terms were identified in the HT-29 tumors. The GO analysis clearly showed that the treatment of the A549 tumors with the hATMSCs upregulated the expression of many genes associated with 'Regulation of cell growth', which has been known to be induced by a potential anticancer drug (38). In contrast, 'Regulation of transcription (DNA-dependent)' and 'Cell-cell adhesion', which have been previously reported to be upregulated in xenograft tumor models and in cancer cell lines $(39,40)$, were suppressed in the A549 tumors following treatment with the
hATMSCs. Lo et al (41) showed that GO biological processes, including 'Nucleosome assembly', 'Nucleosome organization', 'Protein-DNA complex assembly' and 'Chromatin assembly or disassembly' were found to be altered in Asian and Caucasian lung cancer patients. 'Nucleosome assembly' has also been known as a process which alters the regulatory mechanisms of cancer cells (42). In the present study, the hATMSCs downregulated the above-mentioned biological processes in the A549 tumors. In particular, the KEGG pathway analysis indicated that 'Small cell lung cancer pathway' in the downregulated trend gene set was significant in the hATMSC-treated A549 tumors $(\mathrm{p}<0.05)($ data not shown). These findings presented here, suggesting that biological processes possibly associated with the tumor modulation, are active in only A549 tumors, can provide important implications to verify the dual effects of the hATMSCs.

To identify possible genetic factors for hATMSC-induced tumor modulation, the differentially expressed genes in proportion to xenograft tumor size following hATMSC 
administration were identified. Histone proteins, which are basic nuclear proteins responsible for the nucleosome structure of the chromosomal fiber, were expressed from four different clusters in the human genome. In histone cluster 1, mainly histone 1 (e.g. HISTIHIT) and histone 2 (e.g. HIST1H2BC, HIST1H2AC and HIST1H2BD) genes were found to be overexpressed in the cancer tissues (43). Although there are few reports of $H I S T 1 H 2 A J$ which is related to cancer directly, HIST1H2AJ (histone cluster 1, H2aj) was found to be expressed in direct proportion to the xenograft tumor size and is likely to be functionally relevant in tumorigenesis. We also found that NPY4R was differentially expressed in inverse proportion to the xenograft A549 and HT-29 tumor size after hATMSC administration. NPY family peptides, one of the most widely distributed peptides in the central and peripheral nervous system, regulate physiological processes associated with energy homeostasis such as energy expenditure, lipid metabolism and insulin secretion through their actions on Y receptors (44-47). Moreover, the NPY system is known to be involved in cancer development via effects on energy homeostasis, immune function, as well as direct actions on tumor biology (47), raising the possibility of the involvement of NPY4R expression in the regulation of tumor growth following treatment with hATMSCs.

Cell signaling pathways associated with translational changes have been referenced to explain the mechanisms of the conflicting effects of MSCs on tumors. PI3K/AKT was referred as a possible means related to the tumor-inhibitory effect of umbilical cord MSCs (48). WNT (24) and JAK/STAT pathways (17) were also suggested as cell signaling pathways involved in the effects of MSCs. We additionally investigated the expression levels of certain proteins to determine which cell signaling pathways are related to the effects of hATMSCs on tumor growth. First of all, the hATMSCs affected the levels of phosphorylated NF- $\mathrm{B}$ p 65, yet not $\mathrm{p}-\mathrm{JAK} 3$, p-STAT3 or $\beta$-catenin that are also key players in the effects of MSCs on tumors. Second, the hATMSC-induced changes in phosphorylated NF- $\kappa$ B p65 levels were correlated with the hATMSC-associated modulation on A549 and HT-29 tumor growth, suggesting the $\mathrm{NF}-\kappa \mathrm{B}$ pathway as a potential mediator in the effects of hATMSCs on tumors. The NF- $\kappa \mathrm{B}$ pathway is triggered in response to infection or exposure to pro-inflammatory cytokines, leading to inhibitor of $\kappa \mathrm{B}(\mathrm{I} \kappa \mathrm{B})$ degradation and finally translocation of p50/p65 heterodimers into the nucleus. In general, $\mathrm{NF}-\kappa \mathrm{B}$ regulates a variety of downstream genes that govern immunity, cell growth and apoptosis (49). In the tumor environment, the $\mathrm{NF}-\kappa \mathrm{B}$ pathway is widely known to regulate the proliferation of tumor cells through the transcription of anti-apoptotic proteins, leading to the increased growth and metastasis of various types of tumors (50). Actually, in the A549 and HT-29 cancer cells, correlations were reported in which cell proliferation was promoted by activation of the NF- $\kappa \mathrm{B}$ pathway and suppressed by blocking the NF- $\kappa \mathrm{B}$ pathway $(51,52)$, supporting our hypothesis on the possible link of the NF- $\kappa \mathrm{B}$ pathway to the tumor growth modulated by hATMSCs.

Given the possibility of MSCs as a novel therapeutic tool for various diseases, it is critical to explain the conflicting findings in tumor-MSC studies. Despite previous reports on the possible factors of MSC-induced tumor modulation, the exact mechanisms remain unclear. The most direct outcome of the present study is that we confirmed the dual effects of hATMSCs in the two types of cancer cells in different microenvironments in vivo and in vitro. We also suggest the possible roles of the identified gene as profiled and the $\mathrm{NF}-\kappa \mathrm{B}$ pathway in the dual modulatory effects of hATMSCs on tumor growth. Our findings have profound implication in understanding the interaction between MSCs and tumors although further research is needed to confirm these findings using various types of cancer.

\section{References}

1. Dominici M, Le Blanc K, Mueller I, Slaper-Cortenbach I, Marini F, Krause D, Deans R, Keating A, Prockop Dj and Horwitz E: Minimal criteria for defining multipotent mesenchymal stromal cells. The International Society for Cellular Therapy position statement. Cytotherapy 8: 315-317, 2006.

2. Dong J, Uemura T, Shirasaki Y and Tateishi T: Promotion of bone formation using highly pure porous beta-TCP combined with bone marrow-derived osteoprogenitor cells. Biomaterials 23: 4493-4502, 2002.

3. Choi HJ, Kim JM, Kwon E, Che JH, Lee JI, Cho SR, Kang SK, Ra JC and Kang BC: Establishment of efficacy and safety assessment of human adipose tissue-derived mesenchymal stem cells (hATMSCs) in a nude rat femoral segmental defect model. J Korean Med Sci 26: 482-491, 2011.

4. Toyoshima KE, Asakawa K, Ishibashi N, Toki H, Ogawa M, Hasegawa T, Irié T, Tachikawa T, Sato A, Takeda A, et al: Fully functional hair follicle regeneration through the rearrangement of stem cells and their niches. Nat Commun 3: 784, 2012.

5. Seo KW, Sohn SY, Bhang DH, Nam MJ, Lee HW and Youn HY: Therapeutic effects of hepatocyte growth factor-overexpressing human umbilical cord blood-derived mesenchymal stem cells on liver fibrosis in rats. Cell Biol Int 38: 106-116, 2014.

6. Perez-Basterrechea M, Obaya AJ, Meana A, Otero $\mathrm{J}$ and Esteban MM: Cooperation by fibroblasts and bone marrowmesenchymal stem cells to improve pancreatic rat-to-mouse islet xenotransplantation. PLoS One 8: e73526, 2013.

7. Bas E, Van De Water TR, Lumbreras V, Rajguru S, Goss G, Hare JM and Goldstein BJ: Adult human nasal mesenchymallike stem cells restore cochlear spiral ganglion neurons after experimental lesion. Stem Cells Dev 23: 502-514, 2014.

8. Tian LL, Yue W, Zhu F, Li S and Li W: Human mesenchymal stem cells play a dual role on tumor cell growth in vitro and in vivo. J Cell Physiol 226: 1860-1867, 2011.

9. Ra JC, Shin IS, Kim SH, Kang SK, Kang BC, Lee HY, Kim YJ, Jo JY, Yoon EJ, Choi HJ, et al: Safety of intravenous infusion of human adipose tissue-derived mesenchymal stem cells in animals and humans. Stem Cells Dev 20: 1297-1308, 2011.

10. MacIsaac ZM, Shang H, Agrawal H, Yang N, Parker A and Katz AJ: Long-term in-vivo tumorigenic assessment of human culture-expanded adipose stromal/stem cells. Exp Cell Res 318: 416-423, 2012.

11. Klopp AH, Gupta A, Spaeth E, Andreeff M and Marini F III: Concise review: Dissecting a discrepancy in the literature: do mesenchymal stem cells support or suppress tumor growth? Stem Cells 29: 11-19, 2011.

12. Maestroni GJ, Hertens E and Galli P: Factor(s) from nonmacrophage bone marrow stromal cells inhibit Lewis lung carcinoma and B16 melanoma growth in mice. Cell Mol Life Sci 55: 663-667, 1999.

13. Khakoo AY, Pati S, Anderson SA, Reid W, Elshal MF, Rovira II, Nguyen AT, Malide D, Combs CA, Hall G, et al: Human mesenchymal stem cells exert potent antitumorigenic effects in a model of Kaposi's sarcoma. J Exp Med 203: 1235-1247, 2006.

14. Li L, Tian H, Chen Z, Yue W, Li S and Li W: Inhibition of lung cancer cell proliferation mediated by human mesenchymal stem cells. Acta Biochim Biophys Sin 43: 143-148, 2011.

15. Zhu W, Xu W, Jiang R, Qian H, Chen M, Hu J, Cao W, Han C and Chen Y: Mesenchymal stem cells derived from bone marrow favor tumor cell growth in vivo. Exp Mol Pathol 80: 267-274, 2006.

16. Xu WT, Bian ZY, Fan QM, Li G and Tang TT: Human mesenchymal stem cells (hMSCs) target osteosarcoma and promote its growth and pulmonary metastasis. Cancer Lett 281: 32-41, 2009. 
17. Tsai KS, Yang SH, Lei YP, Tsai CC, Chen HW, Hsu CY, Chen LL, Wang HW, Miller SA, Chiou SH, et al: Mesenchymal stem cells promote formation of colorectal tumors in mice. Gastroenterology 141: 1046-1056, 2011.

18. Roorda BD, ter Elst A, Kamps WA and de Bont ES: Bone marrow-derived cells and tumor growth: Contribution of bone marrow-derived cells to tumor micro-environments with special focus on mesenchymal stem cells. Crit Rev Oncol Hematol 69: 187-198, 2009.

19. Mishra PJ, Mishra PJ, Humeniuk R, Medina DJ, Alexe G, Mesirov JP, Ganesan S, Glod JW and Banerjee D: Carcinomaassociated fibroblast-like differentiation of human mesenchymal stem cells. Cancer Res 68: 4331-4339, 2008.

20. Plumas J, Chaperot L, Richard MJ, Molens JP, Bensa JC and Favrot MC: Mesenchymal stem cells induce apoptosis of activated T cells. Leukemia 19: 1597-1604, 2005.

21. Karnoub AE, Dash AB, Vo AP, Sullivan A, Brooks MW, Bell GW, Richardson AL, Polyak K, Tubo R and Weinberg RA: Mesenchymal stem cells within tumour stroma promote breast cancer metastasis. Nature 449: 557-563, 2007.

22. Lu YR, Yuan Y, Wang XJ, Wei LL, Chen YN, Cong C, Li SF, Long D, Tan WD, Mao YQ, et al: The growth inhibitory effect of mesenchymal stem cells on tumor cells in vitro and in vivo. Cancer Biol Ther 7: 245-251, 2008.

23. Otsu K, Das S, Houser SD, Quadri SK, Bhattacharya S and Bhattacharya J: Concentration-dependent inhibition of angiogenesis by mesenchymal stem cells. Blood 113: 4197-4205, 2009.

24. Qiao L, Xu ZL, Zhao TJ, Ye LH and Zhang XD: Dkk-1 secreted by mesenchymal stem cells inhibits growth of breast cancer cells via depression of Wnt signalling. Cancer Lett 269: 67-77, 2008.

25. Kubota T, Yamaguchi H, Watanabe M, Yamamoto T, Takahara T, Takeuchi T, Furukawa T, Kase S, Kodaira S, Ishibiki K, et al: Growth of human tumor xenografts in nude mice and mice with severe combined immunodeficiency (SCID). Surg Today 23 375-377, 1993

26. Denicolaï E, Baeza-Kallee N, Tchoghandjian A, Carré M, Colin C, Jiglaire CJ, Mercurio S, Beclin C and FigarellaBranger D: Proscillaridin A is cytotoxic for glioblastoma cell lines and controls tumor xenograft growth in vivo. Oncotarget 5: 10934-10948, 2014

27. Yun JW, Lee TR, Kim CW, Park YH, Chung JH, Lee YS, Kang KS and Lim KM: Predose blood gene expression profiles might identify the individuals susceptible to carbon tetrachlorideinduced hepatotoxicity. Toxicol Sci 115: 12-21, 2010.

28. Jung KW, Won YJ, Kong HJ, Oh CM, Seo HG and Lee JS Prediction of cancer incidence and mortality in Korea, 2013. Cancer Res Treat 45: 15-21, 2013.

29. Paine-Murrieta GD, Taylor CW, Curtis RA, Lopez MH, Dorr RT Johnson CS, Funk CY, Thompson F and Hersh EM: Human tumor models in the severe combined immune deficient (scid) mouse. Cancer Chemother Pharmacol 40: 209-214, 1997.

30. Hao Y, Huang W, Liao M, Zhu Y, Liu H, Hao C, Liu G, Zhang G, Feng H, Ning X, et al: The inhibition of resveratrol to human skin squamous cell carcinoma A431 xenografts in nude mice. Fitoterapia 86: 84-91, 2013.

31. Ansari D, Bauden MP, Sasor A, Gundewar C and Andersson R: Analysis of MUC4 expression in human pancreatic cancer xenografts in immunodeficient mice. Anticancer Res 34: 3905-3910, 2014.

32. Uchibori R, Tsukahara T, Mizuguchi H, Saga Y, Urabe M, Mizukami H, Kume A and Ozawa K: NF- $\mathrm{BB}$ activity regulates mesenchymal stem cell accumulation at tumor sites. Cancer Res 73: 364-372, 2013.

33. Kéramidas M, de Fraipont F, Karageorgis A, Moisan A, Persoons V, Richard MJ, Coll JL and Rome C: The dual effect of mesenchymal stem cells on tumour growth and tumour angiogenesis. Stem Cell Res Ther 4: 41, 2013.

34. Fierro FA, Sierralta WD, Epuñan MJ and Minguell JJ: Marrowderived mesenchymal stem cells: Role in epithelial tumor cell determination. Clin Exp Metastasis 21: 313-319, 2004.
35. Potapova IA, Gaudette GR, Brink PR, Robinson RB, Rosen MR, Cohen IS and Doronin SV: Mesenchymal stem cells support migration, extracellular matrix invasion, proliferation, and survival of endothelial cells in vitro. Stem Cells 25: 1761-1768, 2007.

36. Qiao L, Xu Z, Zhao T, Zhao Z, Shi M, Zhao RC, Ye L and Zhang X: Suppression of tumorigenesis by human mesenchymal stem cells in a hepatoma model. Cell Res 18: 500-507, 2008.

37. Abdel aziz MT, El Asmar MF, Atta HM, Mahfouz S, Fouad HH, Roshdy NK, Rashed LA, Sabry D, Hassouna AA and Taha FM: Efficacy of mesenchymal stem cells in suppression of hepatocarcinorigenesis in rats: Possible role of Wnt signaling. J Exp Clin Cancer Res 30: 49, 2011.

38. Kim BY, Lee J, Park SJ, Bang OS and Kim NS: Gene expression profile of the A549 human non-small cell lung carcinoma cell line following treatment with the seeds of Descurainia sophia, a potential anticancer drug. Evid Based Complement Alternat Med 2013: 584604, 2013.

39. Creighton C, Kuick R, Misek DE, Rickman DS, Brichory FM, Rouillard JM, Omenn GS and Hanash S: Profiling of pathwayspecific changes in gene expression following growth of human cancer cell lines transplanted into mice. Genome Biol 4: R46, 2003.

40. Lu C, Xiong M, Luo Y, Li J, Zhang Y, Dong Y, Zhu Y, Niu T, Wang Z and Duan L: Genome-wide transcriptional analysis of apoptosis-related genes and pathways regulated by $\mathrm{H} 2 \mathrm{AX}$ in lung cancer A549 cells. Apoptosis 18: 1039-1047, 2013.

41. Lo FY, Chang JW, Chang IS, Chen YJ, Hsu HS, Huang SF, Tsai FY, Jiang SS, Kanteti R, Nandi S, et al: The database of chromosome imbalance regions and genes resided in lung cancer from Asian and Caucasian identified by array-comparative genomic hybridization. BMC Cancer 12: 235, 2012.

42. Yang B, Zhang J, Yin Y and Zhang Y: Network-based inference framework for identifying cancer genes from gene expression data. BioMed Res Int 2013: 401649, 2013.

43. Kavak E, Unlü M, Nistér M and Koman A: Meta-analysis of cancer gene expression signatures reveals new cancer genes, SAGE tags and tumor associated regions of co-regulation. Nucleic Acids Res 38: 7008-7021, 2010.

44. Herzog H: Neuropeptide Y and energy homeostasis: Insights from Y receptor knockout models. Eur J Pharmacol 480: 21-29, 2003.

45. Renshaw D and Batterham RL: Peptide YY: A potential therapy for obesity. Curr Drug Targets 6: 171-179, 2005.

46. Huda MS, Wilding JP and Pinkney JH: Gut peptides and the regulation of appetite. Obes Rev 7: 163-182, 2006.

47. Zhang L, Bijker MS and Herzog H: The neuropeptide Y system: Pathophysiological and therapeutic implications in obesity and cancer. Pharmacol Ther 131: 91-113, 2011.

48. Ma Y, Hao X, Zhang S and Zhang J: The in vitro and in vivo effects of human umbilical cord mesenchymal stem cells on the growth of breast cancer cells. Breast Cancer Res Treat 133: 473-485, 2012

49. Escárcega RO, Fuentes-Alexandro S, García-Carrasco M, Gatica A and Zamora A: The transcription factor nuclear factorkappa B and cancer. Clin Oncol 19: 154-161, 2007.

50. Pikarsky E and Ben-Neriah Y: NF-kappaB inhibition: A doubleedged sword in cancer? Eur J Cancer 42: 779-784, 2006.

51. Zhang J, Xu YJ, Xiong WN, Zhang ZX, Du CL, Qiao LF, Ni W and Chen SX: Inhibition of NF-kappaB through IkappaBalpha transfection affects invasion of human lung cancer cell line A549. Ai Zheng 27: 710-715, 2008 (In Chinese).

52. Kuliková L, Mikeš J, Hýždalová M, Palumbo G and Fedoročko P. $\mathrm{NF}-\kappa \mathrm{B}$ is not directly responsible for photoresistance induced by fractionated light delivery in HT-29 colon adenocarcinoma cells. Photochem Photobiol 86: 1285-1293, 2010. 